\title{
DISCURSO DE POSSE DO PROF. TÉRCIO SAMPAIO FERRAZ JUNIOR NA ACADEMIA PAULISTA DE DIREITO
}

SPEECH DUE OF THE PREFESSOR TERCIO SAMPAIO FERRAZ JUNIOR IN SÃO PAULO ACADEMY

OF LAW

Tércio Sampaio Ferraz Junior*

Tenho a honra de assumir nessa solenidade a cadeira da Academia Paulista de Direito, cujo patrono é Spencer Vampré.

Venho trazido pelas mãos generosas de meu ex-aluno, hoje Professor Titular desta Faculdade, Luís Eduardo Schoueri, a quem rendo minhas homenagens.

Mas se aqui chego neste momento devo muito ao mistério das mãos invisíveis que traçam o destino das coincidências e faz dos acasos uma teia de imprevistos.

Cruzou-me o destino com Spencer Vampré pela primeira vez em 1964. Foi o ano em que faleceu.

Não o conheci pessoalmente. Sabia de suas obras. Soube de sua morte. Mas não sabia de sua vida. Quem ma revelou foi Goffredo Telles Junior, mestre cujo talento da palavra que encanta, fora designado para fazer-lhe a homenagem póstuma.

Em sua pungente oração, pronunciada no dia 28 de agosto de 1964, ele indagava:

\section{Quem foi Spencer Vampré?}

E disse-o de maneira inigualável:

Foi a encarnação do espírito de nossa Academia.

Foi o historiador das Arcadas.

Foi Chave de nossos Mistérios.

Foi ídolo da mocidade.

E foi o cultivador de rosas de nosso pátio de pedra.

Spencer Vampré foi a encarnação do espírito de nossa Academia!

Spencer Vampré foi um mestre desta Casa. Homem de saber jurídico multifário, foi nomeado catedrático de Direito Romano em 1925. Testemunha-lhe o saber já o livro, O caso fortuito nos acidentes de transporte, sua tese de concurso para professor substituto da então chamada Primeira Seção da organização curricular: Filosofia do Direito e Direito Romano. Mas, em conseqüência de um remanejamento ocorrido no currículo da Faculdade, transferiu-se para a cadeira de Introdução à Ciência do Direito, na qual permaneceu até sua aposentadoria, em 1953.

Professor Titular de Filosofia e Teoria Geral do Direito da Faculdade de Direito da Universidade de São Paulo. 
Notável jurista, já publicara, antes de seu concurso, outro livro: Das sociedades anônimas, de 1914. E, como prova de uma incomparável erudição, trouxe a lume, em 1916, sua tradução das Institutas do Imperador Justiniano, comparadas com o Direito Civil Brasileiro.

Sobre o recém promulgado Código Civil de 1916, escreveu dois livros marcantes: $O$ que é o Código Civil e $O$ Código Civil Brasileiro anotado à luz dos Documentos Parlamentares e da Doutrina, ambos de 1917. Ao que seguiu, em 1920, sua primeira obra prima: Manual de Direito Civil Brasileiro, em três volumes. E, ao depois, em 1922, sua obra máxima: Tratado Elementar de Direito Comercial, também em três volumes.

Jurista voltado para o cotidiano, já escrevera, em 1919, um Guia Fiscal das Sociedades Anônimas. Mas, demonstrando notável intuição antecipadora dos tempos em que vivemos, produziu também, em 1917, um intrigante pequeno livro: Existe direito subjetivo sem titular?

Comentava, nele, o pensamento atrevido e inovador de Léon Duguit. Mas, sem dúvida, antecipava nas entrelinhas, a revolução técnica que ocorreria muito tempo depois, a técnica dos interesses difusos, nem de sujeito individual nem de sujeito coletivo. Mais! Um mundo de autorias sem sujeito e de obras sem autores, como nos revela o direito de autor contemporâneo. Obras realizadas em conjunto (obras coletivas), expressão de uma personalidade coletiva, nem sempre individualizável.

Mas um jurista não é um autor, não se reduz à obra que escreveu na quietude de sua mesa de trabalho, pois, um ensimesmado. Ao contrário, põe-se no mundo comum, ao qual não nega a exuberância da inteligência e da personalidade.

Por isso a ele, no seu julgamento sempre atento às coisas do mundo, impõe-se a moderação e a prudência, para não ser engolfado pelo arrebatamento dos argumentos ou pela tirania do verdadeiro. Prudência ou moderação não significa, porém, ausência de paixão. Pois o jurista, ao produzir suas obras, introduz, no âmbito da verdade ou da qualidade e do talento argumentativos, o fator pessoal, ou seja, confere-lhes uma significação humana. $\mathrm{O}$ autêntico jurista cuida de seus objetos à sua própria maneira "pessoal”, humanizando, assim, o mundo dos argumentos. Ele é, em seu sentido próprio, inexoravelmente humanista, homem que sabe como preservar, admirar e cuidar das coisas do mundo, sem a elas se escravizar.

Em sua aula inaugural de 1932, dizia Spencer Vampré:

Perceberam os apaixonados da natureza, que o só segredo de vencê-la consiste em obedecer-lhe às leis, e por isso a primeira vaidade de que se despiram foi da soberba com que julgaram infinita a supremacia da razão. Aprenderam a querêla e estimá-la, na aparente desordem de seus fenômenos, mas na profunda unidade de seus princípios, e a amá-la 
estranhamente, amando os progressos do espírito humano, não já com o orgulho envaidecido de quem julga tudo saber e poder tudo, mas na coragem obstinada e prudente de quem conhece os limites da humana sabedoria.

Nesse contexto, para Spencer Vampré, o direito não seria produto de uma razão abstrata nem racional por força de um ideal inatingível. Mas de uma experiência que medra nas interfaces do cotidiano.

Em notável síntese, dizia ele: "em torno de nós, ao alcance de nossos olhos, estão as leis que buscamos" (As leis fundamentais da evolução jurídica).

Donde seu apelo: "Não procuremos os princípios do direito ao sabor das nossas conveniências políticas, ou do que pareça ser as nossas conveniências políticas. Ergamos os nossos olhos para os princípios da justiça, que aí também encontraremos o que é soberanamente útil" ( $O$ que é o Código Civil).

Spencer Vampré foi o historiador das Arcadas!

Foi no respeitoso inclinar-se perante o passado que os traços mais significativos de Spencer Vampré se revelam.

Ao escrever o prefácio de suas Memórias para a História da Academia de São Paulo, editadas em 1924, dizia ele que aquela edição era preparatória para a que se publicaria no centenário da fundação dos cursos jurídicos. E arrematava: "Pedem-se, por isso, encarecidamente, novos subsídios, a quem quer que os possa dar, e também as correções ao que se achar inexato ou omisso".

Obra de um, aberta a todos!

Como se o autor tivesse o senso do tempo passado, que não se reconstitui na memória individual, mas é o produto da memória coletiva. Por isso também, ao final do segundo volume, percebia com acuidade que a história é um passado interrompido, compartimentado pela percepção do historiador. Mas que essa interrupção ocorre num tempo contínuo, que se abre para o futuro. Daí que os episódios e os personagens, tanto os retratados quanto os omitidos, "constituem a aristocracia intelectual, que continuará a nortear os destinos da Pátria, como o fizeram as gerações precedentes".

Suas Memórias têm, por isso, o sentido de uma reconstituição, a reconstituição dos feitos e dos sofrimentos de seres humanos, e, ao mesmo tempo, conta os eventos que afetaram suas vidas, como o único processo cuja existência é exclusivamente uma realização humana. Não se trata, pois, apenas de um conjunto de ações humanas, recolhidas do seu acontecer efêmero, mas sim da própria experiência humana, cujo sentido mais profundo é o de um acabamento que não se acaba.

Spencer Vampré foi ídolo da mocidade!

Daí, sem dúvida, o apelo à mocidade, que aparece ao final do texto de suas Memórias: 


\section{"Eia, avante, eia, avante! \\ Que o Brasil sobre vós ergue a fé; \\ Esse imenso colosso gigante \\ Trabalhai por erguê-lo de pé!'}

Lembro-me, nesse momento, pouco antes de 31 de março de 1964, de reuniões angustiadas, nas dependências do Onze de Agosto, cercado pela Força Pública, de cacete em mão, que nos obrigava, estudantes à época, a buscar refúgio no Convento de São Francisco, com cujas paredes se confrontava, ao fundo, e onde havia uma "passagem" esquecida.

Lembro-me, também, do terror, à noite, das tropas espalhadas em torno da Faculdade, por ocasião de uma palestra política realizada na Sala dos Estudantes, e do susto apavorante, diante da ordem "salve-se quem puder", quando, ao dobrarmos a esquina, na direção da Rua Riachuelo, topávamos com um "brucutu”, nome dado a uma espécie de "viatura-tanque de guerra", destinado coibir manifestações "subversivas".

Lembro-me, ainda, da escolha desaforada do paraninfo de minha turma, em 1964, Prof. Goffredo Telles Junior, que iria tornar-se um baluarte na defesa das instituições democráticas, culminante pela leitura, em 1977, no velho pátio, de sua "Carta aos Brasileiros", episódio marcante da virada política em favor da ordem jurídica de base democrática.

Mas lembro-me, sobretudo, da eleição do Patrono da Turma.

Sempre se homenageava o nome de um jurista recém falecido. Naquele ano de 1964, Waldemar Ferreira era um deles. Jurista ilustre, político ligado à UDN, sua escolha conhecia resistências ideológicas, por ser considerado um político conservador. De outro lado, Santiago Dantas. Mas Santiago era um símbolo indesejado no contexto do regime militar que se instalara. E em meio à polarização política, da dialética entre a resistência e a opressão oficial, acabou por prevalecer uma síntese insuspeita: Spencer Vampré, patrono da turma de 1964!

Fora uma escolha peculiar num jogo quase dialético de oposições.

Não se tratava, na verdade, de uma síntese de oposições iluminadas: tanto Waldemar Ferreira como Santiago Dantas conviviam em harmonia no caráter ilustre da sua respectiva obra jurídica.

Nem se tratava de uma síntese de ideários políticos, pois a dialética que os opunha não era deles, era nossa. E ocorria num momento, como aquele de 1964, em que a rebeldia calada dos estudantes ainda conseguia falar através do silêncio que se lhes impunha.

Na verdade, a escolha de Spencer Vampré era uma síntese quase dialética que não se dimensionava nem no plano da realidade dos fatos nem no plano da racionalidade das idéias. 
Quem nos fizera perceber e sentir essa outra dimensão fora Goffredo Telles Junior, que, em sua pungente homenagem póstuma, na oração pronunciada no dia 28 de agosto de 1964, nos dissera:

\begin{abstract}
Quando tudo não tem mais sentido, e a vida é menos do que nada, não será a remota vibração dessa Utopia, que nos faz insistir e continuar? E quando tudo parece terminado, não haverá, nas profundezas da subconsciência, as névoas (...), e no recesso mais oculto do coração, o calor insuspeitado de uma indefinível esperança? Que seria a vida se não fosse o Sonho?
\end{abstract}

Spencer Vampré fora a Chave de nossos Mistérios.

Patrono da turma de 1964 era uma síntese dialética no plano dos sonhos.

Não, porém, do sonho que se iguala aos sonhos do homem comum. Não, assim, o sonho subjetivo, o sonho que alguém acalenta no seu íntimo e dele faz uma aspiração própria mesmo quando essa aspiração própria é uma redenção social, voltada para os outros.

Não! O sonho de Spencer Vampré fora, na palavra de Goffredo, o sonho do Grande Mistério. O sonho da tragédia que o acometera, da doença insidiosa e incurável que transtornara sua vida. Um sonho de loucura, mas daquela loucura que nos purifica, nos propulsiona, nos enleva e nos redime.

Não, portanto, o sonho do homem comum, mas o sonho da comunidade dos homens. Cujo lastro é a generosidade da alma e cuja essência não é feita de renúncia, mas de dádiva. Um sonho ao qual o mundo real não interessa, nem interessa o mundo racional da ciência e da técnica. $\mathrm{O}$ sonho do amor sem correspondências e exigências. $\mathrm{O}$ sonho de quem, um dia, como Diretor da Faculdade de Direito do Largo de São Francisco, foi capaz de fretar um navio para toda a Academia, para levá-la, como disse ele, "pelos mares eu sei onde".

Spencer Vampré, o cultivador de rosas de nosso pátio de pedra!

Eis aí o sonho de Spencer Vampré, que era, seguramente, a mais forte expressão dessa síntese permanente e duradoura, que sublima tudo o que um homem escreveu e concebeu, que paira, inatingível, por entre as disputas jurídicas que travamos e disputamos.

Que faz do próprio direito essa atividade singular, que exige preparo, inteligência e acuidade, mas também intuição, espontaneidade e encantamento.

Que, por isso, para compreendê-lo, exige, afinal, sabedoria e amor.

Pois só o homem que sabe pode ter-lhe o domínio. Mas só quem o ama é capaz de dominá-lo, rendendo-se a ele. 


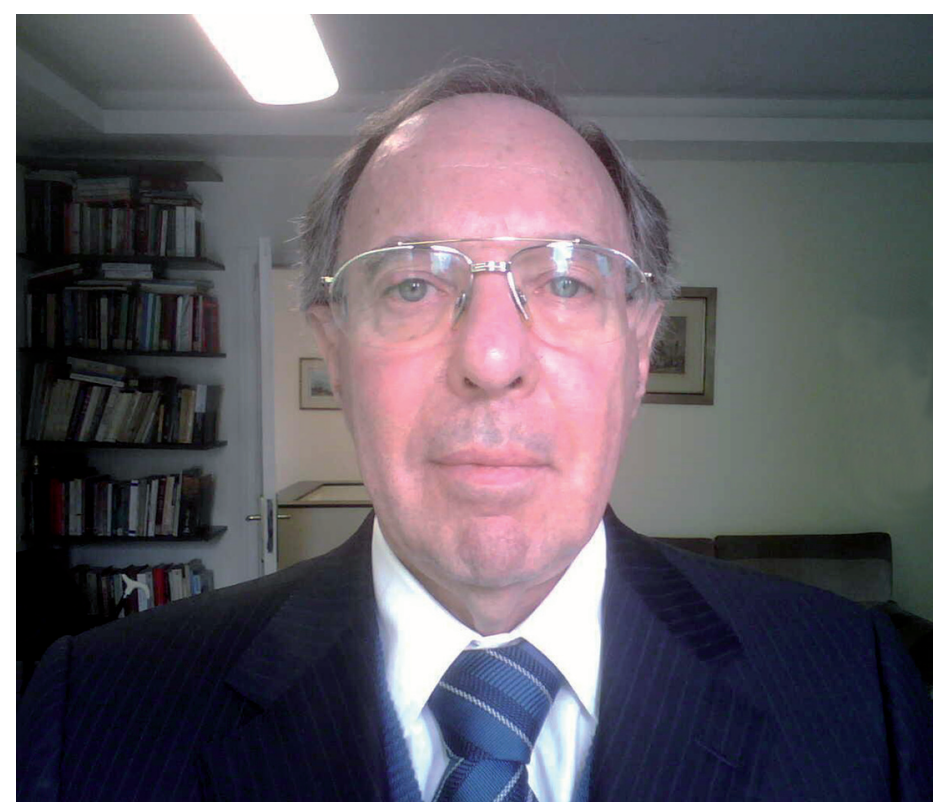

Professor Titular Tércio Sampaio Ferraz Junior 